\title{
Innovation and Competitiveness of European Regions
}

\author{
Michele Sabatino $^{1, *} \&$ Giuseppina Talamo ${ }^{1}$ \\ ${ }^{1}$ Faculty of Business and Law, University of Enna "KORE", Viale delle Olimpiadi - \\ Cittadella Universitaria - 94100 ENNA, Italy \\ "Correspondence: University of Enna "KORE", Viale delle Olimpiadi - Cittadella \\ Universitaria, 94100 ENNA, Italy. E-mail: michele.sabatino@unikore.it
}

Received: August 4, 2017 Accepted: August 23, 2017 Published: September 7, 2017

doi: 10.5296/rae.v9i3.11642ＵRL: https://doi.org/10.5296/rae.v9i3.11642

\begin{abstract}
The recent debate on European development policies is articulated around two major filelds of researches that are highly integrated with each other. One of this is investments in research, innovation and the innovative capacity of the European regions. Another is the degree of competitiveness of production and European regional systems. This research enters the debate on development and regional competitiveness related to innovation and research, by presenting recent data on innovation and competitiveness in the different European regions. Firstly we present the degree of innovation of European regions referring one of the main document "The Regional Innovation Scoreboard 2016". This document provides a comparative assessment of the performance in terms of innovation in 190 regions of the EU, making use of a limited number of indicators of research and innovation. It also shows what the differences in the level of innovation performance among EU Member States are still considerable and are reduced only slowly. Secondary we present recent data on the degree of competitiveness of the regions by specifying the selected indicators of competitiveness within the EU with a base map existing (The Europe 2020 Competitiveness Report 2014). The aim of this paper is to understand the correlation between the degree of innovation and the degree of competitiveness comparing first the above mentioned dataset and mapping the most innovative and competitive regions. In the light of this comparison the differences and similarities will be highlighted, as well as the correlation between the index of innovation and to regional competitiveness. At the end are presented some policy indications on possible courses of action for innovation and competitiveness of European regions.
\end{abstract}

Keywords: development policies, innovation, competitiveness, European regions 


\section{Introduction}

This paper presents a review of the main research and policies on the relationships between innovation and competitiveness at European level. In particular, this paper provides a comparative assessment of innovation performances in the EU regions making use of index of regional innovation and competitiveness: RIS - Regional Innovation Scoreboard Index and RCI - Regional Competitiviness Index.

Literature on innovation and competitveness topic is vast. Economic analysis, both a theoretical and at empirical levels, has long been investigating the role of innovation in generating growth and competitiveness. Innovation has been cited as one of the key factors that affects competitiveness. The link between innovation and economic trends has been broadly in-depth and analyzed at microeconomic and macroeconomic level). Despite widespread agreement about its benefits, innovation as concept is still poorly understood. In this terms, research and development spending, the ability to have human capital with outstanding technical and scientific skills, the presence of a consolidated system of relationships between universities, research centers and businesses are factors that can create new knowledge which in turngenerates, in a favorable context, growth and economic development (Quadrio Curzio - Fortis - Galli, 2002; Quadrio Curzio - Fortis, 2007).

In the light of all different definitions, interpretations and indices of the term innovation we consider appropriate to proceed in this work by analyzing the concept of innovation, first related to competitiveness and second as a factor that can generate growth and economic development. Bodies of research on the relationship between innovation and competitiveness include: econometric and statistical analyses, economic models, micro or macro case studies. If on one hand Regional Innovation is considered as a fundamental driver for economic growth and competitiveness in Europe on the other hand also competitiveness enters in the debate strengthening development in the different European regions.

Recent studies (Asheim et al., 2015) on innovation and competitiveness (e.g., Innovation Scoreboard, Regional Innovation Monitor, Regional Competitiveness Report etc.) are a clear evidence of the growing interest in measuring and illustrating relationships between innovation-competitiveness and economic growth at various levels (regional, national, EU). Such multi-level policies should be considered as central determinants to frame strategies which are smart, inclusive and eventually linked to principles of sustainability and territorial cohesion.

Consistently with these concepts, EU Regions have been identified as the crucial actors along the Research and Innovation (R\&I) policy process. Regional authorities are expected in fact to concentrate public resources on a few development priorities in innovation, to outline measures to stimulate private $\mathrm{R} \& \mathrm{D}$ investment, to build on competitive advantages along their value chain, to foster stakeholder involvement through an innovative governance while supporting evidence-based policy and programmes that include a sound monitoring and evaluation system.

This paper contributes to this debate by presenting a comparative analysis between 
innovation and competitiveness. The aim of this paper is to compare, at regional level, the degree of innovation and the degree of competitiveness comparing first the above mentioned indices. This analysis allows building a European map that compare the most innovative regions and the most competitive regions. In the light of this comparison the differences and similarities will be highlighted, as well as the correlation between the index of innovation and regional competitiveness. At the end the paper will present some policy indications on possible courses of action for innovation and competitiveness of European regions.

\section{The Theoretical Framework of Concepts of Innovation and Competitiveness}

\subsection{The concept of Regional Innovation System}

There is a widespread consensus in academic and policy debates that knowledge and innovation are eminently important for securing competitiveness, dynamic growth and prosperity of regional economies. The regional innovation system (RIS) approach figures prominently in scholarly discussions about the uneven geography of innovation and factors that shape knowledge generation and innovation capacities of regions. Since its development in the 1990s, RIS has attracted considerable attention from economic geographers and innovation scholars. Protagonists of the RIS notion have convincingly argued that the question of regional scale is essential in understanding new knowledge creation and its economic exploitation.

The RIS concept combines insights from the literature on innovation systems (Lundvall 1992; Nelson 1993; Freeman 1995; Edquist 1997) with the simultaneously burgeoning contributions on territorial innovation models (Moulaert and Sekia 2003).

Simultaneously to the emergence of the innovation systems approach in the 1980 s, the concept of industrial districts was rediscovered and used to explain the success of post-Fordist regions characterized by flexible production systems and tight inter-firm networks giving rise to external economies of scale (Brusco 1982; Pyke, Becattini, Sengenberger 1990; Asheim 2000). It was a revival of Marshall's (1920) ideas on the importance of local and regional context for the exchange of knowledge, the development of a local labour market and supplier industries. A large body of related work contributes to unveiling how regional context conditions shape innovation performance, including research on learning regions (Asheim 1996), innovative milieu (Camagni 1995; Maillat 1998a; Crevoisier 2004), and clusters (Swann and Prevezer 1996; Baptista - Swann 1998; Porter 1998, 2000; Maskell 2001).

Common to these territorial innovation models (Moulaert and Sekia 2003) we can find a systemic perspective for which innovation results from interactive learning processes between different types of actors. This approach offers an unifying framework for these models despite all specificities of each model (Asheim, Smith, Oughton 2011). Innovation systems are per definition an open systems (Clark and Guy, 1998) which raises the following questions: how to delineate innovation systems and how to draw boundaries? The rationale for applying a system perspective a regional level lies in the importance of geographic 
proximity for knowledge exchange and interactive learning as well as the role of the region in meso-level governance.

In this sense, the RIS approach emphasizes the importance of geographic proximity for knowledge transfer and learning and thereby legitimizes the regional perspective on innovation systems. Knowledge is partly tacit and thus difficult to transfer over distance (Polanyi 1958). Malmberg and Maskell (1999, p. 180) argue that the proximity argument relates to the "time geography of individuals". Everything else being equal, interactive collaboration will be cheaper and smoother, the shorter the distance between the participants." Furthermore, tacit knowledge is embedded in a social, cultural and institutional context and as Gertler (2004) shows in his empirical investigation on German manufacturers operating in the US, tacit knowledge may lose its value when applied in other contexts. Geography is also important due to the spatial bias of social networks facilitating the circulation of knowledge (Granovetter 1973, 2005). The main reason for the spatial bias is that geographic proximity is important in establishing social networks (Agrawal, Cockburn, McHale 2006). This is intensified by the low mobility of labour. Breschi and Lissoni (2009, p. 460) find evidence that "[t]he fundamental reason why we observe geographical localization of patent citations is the low propensity of a special category of knowledge workers and providers of knowledge intensive services (the inventors) to relocate in space." Furthermore, the dominant geographic scale for sourcing knowledge through recruitment is regional (Grillitsch, Tödtling, Höglinger 2013; Plum and Hassink 2013).

Regions often represent important levels of governance situated between the local and municipal level, as well as the national and the international level. According to Howells (1999, p. 72) three dimensions define the importance of the regional level, namely: " 1 . the regional governance structure, both in relation to its administrative set-up and in terms of legal, constitutional and institutional arrangements; 2. the long-term evolution and development of regional industry specialisation; 3. additional core/periphery differences in industrial structure and innovative performance." The relative independence and strength of regional government like in Austria or Germany, or the weakness of national government like in Italy can be important drivers for the emergence of RIS (Asheim - Isaksen 1997). For example, the success of Baden-Württemberg's technology policy was to a large extent contingent on the federalist form of governance in Germany, which provides for independence, resources as well as high competencies of the regional government. However, even without legislative autonomy and funding opportunities, regions can play an important role in coordinating innovation activities and supporting the local industry, exemplified by Emilia-Romagna in Italia (Bianchi- Giordani 1993). Consequently, an innovation system perspective is often justified at regional level.

This, however, does not yet tell us much about what RIS actually are. RIS understood in a narrow sense comprise two sub-systems, one capturing actors exploring and generating new knowledge and another one encompassing firms engaged in the exploitation of innovations. The knowledge exploration sub-system typically refers to universities, public and private research organisations, technology mediating organisations, workforce mediating organisations and educational organisations. The knowledge exploitation system relates to 
firms, often organised in one or several clusters potentially with horizontal networks between competitors and collaborators and vertical networks along the value chain. In a broad sense, RIS encompass all regional economic, social and institutional factors that affect the innovativeness of firms (Lundvall 1992). The broad perspective views the two sub-systems as being embedded in an institutional and organisational support infrastructure for innovation. (Autio 1998; Cooke 1998; Tödtling and Trippl 2005; Asheim 2007).

Moreover, RIS are systemic due to the networks and interactions between the actors. Hence, it is questionable to speak about a regional innovation system if there is a lack of interactions of regional actors within and between the two sub-systems. These interactions are perceived to be socially embedded. Thus, the two dimensions of social capital, i.e. social networks and shared norms, values and a culture of trust (Putnam 1995; Burt 2000), are assumed to contribute to interactive learning and thus the functioning of RIS. Accordingly, the RIS approach places a stronger emphasis on informal institutions as compared to the national variant. However, common to both, the national and regional innovation system approach, is the central role of innovation policy for shaping the conditions for innovation and thus for constructing regional advantage (Asheim, Moodysson, and Tödtling 2011; Tödtling, Asheim, Boschma 2013).

From the above, a clear distinction can be made between the RIS and all antecedents like industrial districts, innovative milieus or industrial clusters. From the start, these concepts zoomed in on interrelated firms in one or related industries that are co-located in space. As the cluster literature evolved, the importance of knowledge exploration to promote innovativeness has surfaced. The RIS approach, however, is more general and encompassing insofar as it looks at the systemic integration of these elements in a region, including the institutional and organisational support structures. A RIS furthermore can capture one (e.g. in a specialised region) or a variety of clusters in different stages of development (Tödtling \& Trippl 2004).

This implies, furthermore, that RIS are arguably more relevant units of analysis for structural change (even if the existing literature suffers often from a static perspective) than for instance industrial clusters. The reason is that new path of development often results from the combination of related or unrelated industries, knowledge bases, and economic activities, thus from combinations that transcendent cluster boundaries.

The RIS approach has essentially contributed to a better understanding of the geography of innovation. Its advocates have offered rich explanations for the sources and dimensions of the variegated nature of regional innovation, that is, why and in what respects innovation activities differ between regions. Finally, in the light of all that RIS concepts, we will try to understand the link between innovations and competitiveness of European regions.

\subsection{Literature Overview on the Regional Competitiveness}

The notion of competitiveness of regions remains an area of contested theoretical debate, with some authors arguing that firms compete for resources and markets. Nevertheless, a significant forum of scholarly and practitioner-based research has developed, in recent years, 
with the aim of theorising upon and empirically measuring the competitiveness of regions. However, the disparate and fragmented nature of these approaches has led to the lack of a substantive theoretical foundation underpinning the various analyses and measurement methodologies employed.

Competitiveness of regions generally refers to the presence of conditions that enable firms to compete in their chosen markets and for the value that these firms generate and to be captured within a particular region (Begg, 1999; Huggins, 2003). Regional competitiveness, therefore, consists on the capability of a particular region to attract and maintain firms with stable or rising market shares in an activity, while maintaining stable or increasing standards of living for those who participate in it (Storper, 1997). Given this, competitiveness may vary across geographic space, as regions develop at different rates, depending on the drivers of growth (Audretsch and Keilbach, 2004).

While the competitiveness of regions is intrinsically bound to their economic performance, there exists a growing consensus that competitiveness is best measured in terms of the assets of the regional business environment (Malecki, 2004, 2007). These include the level of human capital, the degree of innovative capacity, and the quality of the local infrastructure all of which affect the propensity to achieve competitive advantage in leading-edge and growing sectors of activity. The influence that assets and other externalities have on firm competitiveness, such as the ability of regions to attract creative and innovative people or provide high-quality cultural facilities, are all important features of regional competitive advantage (Kitson et al., 2004). In other words, competitiveness is increasingly concerned with creativity, knowledge, and environmental conditions, rather than being purely based on accumulated wealth (Huggins, 2003).

Economic literature is now full of research and analysis on regional competitiveness. As Martin (2005) outlines, concern with competitiveness has filtered down to the regional, urban, and local levels, particularly the role of regionally based policy interventions in helping to improve the competitiveness of regions and city-regions. In many advanced nations, these interventions form part of a strategic framework to improve productive and innovative performance. From this policy perspective, the key drivers of regional competitiveness are usually considered to consist of the enhancement of knowledge and creativity through clusters (Porter, 1998) or networks (Huggins and Izushi, 2007) of firms and complementary organisations. This perspective resembles the views of the endogenous school of regional development, which argues that regions themselves act as an organisational form of coordination facilitating sustainable competitive advantage (Courlet and Soulage, 1995; Garofoli, 2002; Lawson and Lorenz, 1999; Maillat, 1998b).

Despite these developments, both the concept and the measurement of competitiveness at a regional level remain a contested areas of analysis, with some suggesting that "competitiveness league tables are inevitably seductive for regional development agencies and the media keen to absorb 'quick and dirty' comparative measures of regional economic performance" (Bristow, 2005: 294). When conceptualising regional competitiveness, it is crucial to distinguish it from the concept of competition. Certainly, by writing in terms of 
competitiveness, one inevitably invites the reader to think of head-to-head conflict. Yet, the concept of competitiveness a national or regional level is only competitive in the sense that it refers to the presence of conditions that will enable firms to compete in local, national, and international markets. Regions 'compete' in trying to provide the best platform for operating at high levels of productivity, but this is very different from the kind of direct competition undertaken by firms. It is the zero-sum conceptualisation of regional competitiveness which often leads to the premise that there must inevitably be both winners and losers (Bristow, 2005).

Malecki (2004) usefully distinguishes between low road and high road competition. As he points out, regions may compete on the basis of low wages, docile labour, and low taxes, but such low road competition will simply perpetuate an inability to upgrade to an economic base with higher skill and wages. Conversely, competition on the high road involving, for example, knowledge policies aimed at promoting entrepreneurship and knowledge-based economic development, can lead to positive-sum outcomes that bring benefits to all regional economic and social activities (Leborgne and Lipietz, 1988; Malecki, 2004). For regions, therefore, it is important that competitiveness not only leads to increasing market shares in a particular industry but also raises, or at least maintains, the standard of living, as this should be the end goal of competitive activity (Aiginger, 2006; Storper, 1997). In general, regional development concerns the upgrading of the economic, institutional, and social base, with entrepreneurship that is able to unlock wealth being a prime source of development (Amin, 1999). Consequently, entrepreneurship is central to regional economic growth and competitiveness (Audretsch and Keilbach, 2004; Malecki, 2007).

Spatial economics which does not incorporate entrepreneurship factors may fail to understand and identify key sources of regional development, with regions that are open and creative often able to attract human capital and enjoy more dynamic entrepreneurship (Benneworth, 2004; Lee et al., 2004). In a competitive environment, entrepreneurs will be alert to opportunities and contribute to regional economic growth (Audretsch and Keilbach, 2004). However, changes in levels of entrepreneurship and contributions to regional economic development will take time to emerge, and as such, any effects are only likely to be seen in the long term (Huggins and Johnston, 2009; Huggins and Williams, 2009). Alternatively, regions can be uncompetitive and lack entrepreneurial dynamism because they lack key strengths which make leading regions prosper (Benneworth and Charles, 2005; Chaston, 2009; Huggins, 1997; Huggins and Johnston, 2009; Huggins and Williams, 2011; Lagendijk and Lorentzen, 2007; North and Smallbone, 2000; Virkkala, 2007).

As already indicated, regional competitiveness remains a contested concept. However, Krugman $(1994,2003)$, suggests that the competitiveness of a region is based on its ability to provide sufficiently attractive wages and/or employment prospects and a return on capital. This proposition, along with others, has led to competitiveness becoming a more generally accepted concept when discussing uneven development across regions. Camagni (2002) further argues that the concept of regional competitiveness is a theoretically sound, due to the role that territories play in providing competitive environmental tools to firms and in the processes of knowledge accumulation. 


\section{The Methodology Used}

While economic theory only relates innovation and competitiveness a the firm level, the existence of such a link at macro level is taken for granted. However, providing evidence of this link is even trickier, as measuring innovation and competitiveness performance is much more problematic when applied at the macro level. There are no universally accepted measures of regional innovation and competitiveness performance. Due to their complex nature, indeces attempt to quantify these notions rely on composite measures derived from a variety of lower level indicators.

This paper is based on the idea that the competitiveness of European regions is necessarily linked to regional innovation systems and that a good understanding of the relationship between innovation and competitiveness is indispensable to assess its effects and economic policies capable of increase the level of competitiveness and growth of European regions. In this regard, we intend to understand the correlation between regional innovation systems and the level of competitiveness of European regions.

Starting from this objective, this paper uses two main indices of regional innovation and competitiveness: RIS-Regional Innovation Scoreboard Index and RCI-Regional Competitiviness Index, pubblished from the European Commission. The aim is, first, to assess the degree of correlation between these two indices for all European regions and, second try to answer to the following question: how important this relationship is for regional policy choices?

In the Regional Innovation Scoreboard (RIS), regional innovation performance should ideally be measured using the full measurement framework of the European Innovation Scoreboard (EIS), i.e. using regional data for the same indicators applied to measure innovation performance at the country level. However, for many indicators used in the EIS, regional data are not available. RIS is limited to regional data for 12 of the 25 indicators used in the EIS (Table 1).

The RIS innovation inputs include three dimensions:

- Enablers (3 indicators), which measure some key aspects of the innovation potential, in particular, related human resouces and finance and support;

- Firm Activities (3 indicators), which measure firm investments, linkeges \& enterprneurship, intellectual assets;

- Outputs (2 indicators), which measure the innovators and economic effects.

The Regional Competitiviness Index (RCI) adopts and builds on the methodology developed by the World Economic Forum (WEF) Global Competitiveness Index with some key differences, mainly due to the RCI's European and regional dimension. Regional competitiveness generally relate to all those factors that impact on the ability of regional businesses to compete in international markets in a way that provides people with the opportunity to improve their quality of life. The RCI is composed of 11 pillars, including institutions, infrastructure, macroeconomy, health, education and training, market efficiency, 
financial markets, technological readiness, market size, business sophistication and innovation, that describe the different aspects of competitiveness. They are classified into three groups: Basic, Efficiency and Innovation.

Considering that and according to the main literature, one possible way of relating regional innovation performance to regional competitiveness is by juxtaposing these measures on a scatter diagram. In order to present all different regions, regional innovation performance is based on the RIS indexr, whereas regional competitiveness is based on Regional Competitiveness Index. Once considered these two indices and based on data for all European regions, we expect that the scatter diagram will shows a strong positive association between regional innovation performanceand regional competitiveness. Such a positive association comes as no surprise since - following the arguments outlined above innovation is indeed regarded as a key driver of economic competitiveness. Moreover, composite regional competitiveness indices as a rule incorporate indicators reflecting innovation performance.

This positive association alone does not imply anything on the direction of causality but the whole discussion suggests that the main direction of causality is from innovation performance to regional competitiveness. By contrast, it can be argued that not all aspects of regional competitiveness are necessarily related to innovation performance. Thus, as argued below, framework conditions related to institutions, infrastructure, macroeconomic stability, etc. which are usually incorporated in regional competitiveness indexes are necessary but not sufficient conditions for higher innovation performance.

\section{The Results and the Data Analysis}

\subsection{Regional Innovation Scoreboard (RIS) indicators, regions and data availability}

Regional Innovation Scoreboard (RIS) provides a comparative assessment of innovation performance across 214 regions of 22 EU Member States and Norway. In addition, Cyprus, Estonia, Latvia, Lithuania, Luxembourg and Malta are included a the country level, as the regional administrative level as such does not exist in these countries. The RIS accompanies the European Innovation Scoreboard (EIS) which benchmarks innovation performance at the level of Member States(Note 1). Where the EIS provides an annual benchmark of the innovation performance of Member States and other European countries, regional innovation benchmarks are less frequent and less detailed due to a general lack of innovation data a the regional level. Regional Innovation Scoreboard addresses this gap by providing statistical facts on regions' innovation performance. Compared to the EIS, the RIS has a stronger focus on the performance of small and medium-sized enterprises (SMEs).

Similar to the EIS, where countries are classified into four innovation performance groups, Europe's regions have been classified into regional Innovation Leaders (36 regions), regional Strong Innovators (65 regions), regional Moderate Innovators (83 regions) and regional Modest Innovators (30 regions). Innovation Leaders are those regions with a relative performance, as measured by the Regional Innovation Index, of $20 \%$ or more above that of 


\section{MInstitute Macrothink $_{\text {Int }}$}

the EU28 average; Strong Innovators are those regions with a relative performance, as measured by the Regional Innovation Index, less than $20 \%$ above but less than $10 \%$ below that of the EU28 average; Moderate Innovators are those regions with a relative performance, as measured by the Regional Innovation Index, more than $10 \%$ below but less than $50 \%$ below that of the EU28 average; Modest Innovators are those regions with a relative performance, as measured by the Regional Innovation Index, of $50 \%$ or less of that of the EU28 average.

The RIS 2016 replicates the European Innovation Scoreboard methodology used at national level to measure performance of regional systems of innovation. The RIS 2016 uses data for 12 of the 25 indicators used in the EIS for 214 regions across Europe (Table 1). Compared to the RIS 2014, the number of indicators has increased thanks to the availability of regional data on exports of medium-high and high technology-intensive manufacturing industries. As both Germany and Greece are now covered at the NUTS2 level, the nominal number of regions covered has increased as well.

Table 1. Indicators of the Regional Innovation Scoreboard

\begin{tabular}{|c|c|}
\hline \multicolumn{2}{|c|}{ ENABLERS } \\
\hline \multicolumn{2}{|c|}{ Human resources } \\
\hline 1 & Percentage population aged 30-34 having completed tertiary education \\
\hline \multicolumn{2}{|c|}{ Finance and support } \\
\hline 2 & R\&D expenditure in the public sector as percentage of GDP \\
\hline \multicolumn{2}{|c|}{ FIRM ACTIVITIES } \\
\hline \multicolumn{2}{|c|}{ Firm investments } \\
\hline 3 & R\&D expenditure in the business sector as percentage of GDP \\
\hline 4 & Non-R\&D innovation expenditures as percentage of total turnover \\
\hline \multicolumn{2}{|c|}{ Linkages \& entrepreneurship } \\
\hline 5 & SMEs innovating in-house as percentage of SMEs \\
\hline 6 & Innovative SMEs collaborating with others as percentage of SMEs \\
\hline \multicolumn{2}{|c|}{ Intellectual assets } \\
\hline 7 & EPO patent applications per billion regional GDP (PPS€) \\
\hline \multicolumn{2}{|c|}{ OUTPUTS } \\
\hline \multicolumn{2}{|c|}{ Innovators } \\
\hline 8 & SMEs introducing product or process innovations as percentage of SMEs \\
\hline 9 & SMEs introducing marketing or organisa $\neg$ tional innovations as percentage of SMEs \\
\hline \multicolumn{2}{|c|}{ Economic effects } \\
\hline 10 & $\begin{array}{l}\text { Employment in medium-high and high tech manufacturing and knowledge-intensive services } \\
\text { as percentage of total employment }\end{array}$ \\
\hline 11 & $\begin{array}{l}\text { Exports of medium-high and high technology-intensive manufacturing industries as percentage } \\
\text { of total manufacturing exports }\end{array}$ \\
\hline 12 & Sales of new-to-market and new-to-firm innovations as percentage of total turnover Similar \\
\hline
\end{tabular}




\section{Macrothink}

Research in Applied Economics

ISSN 1948-5433

2017, Vol. 9, No. 3

Analysis RIS reports emerge that years used in the titles of all reports refer to the years in which respective editions were published, i.e. RIS 2014, RIS 2012, RIS 2009 and RIS 2006. For RIS 2016, most recent data refer to 2014 for two indicators, 2013 for three indicators, 2012 for six indicators and 2011 for one indicator. A reference to the most recent performance year (RII2016) in this report should thus be interpreted as referring to data two to three years prior to the 2016 reference year.

Regional innovation performance is measured using a composite indicator - the Regional Innovation Index (RII) - which summarizes the performance on the indicators. In particular Regional Innovation Index (RII) is calculated as the unweighted average of the normalised scores of the 12 indicators. A geographical map of the regional performance groups is shown in Figure 1.

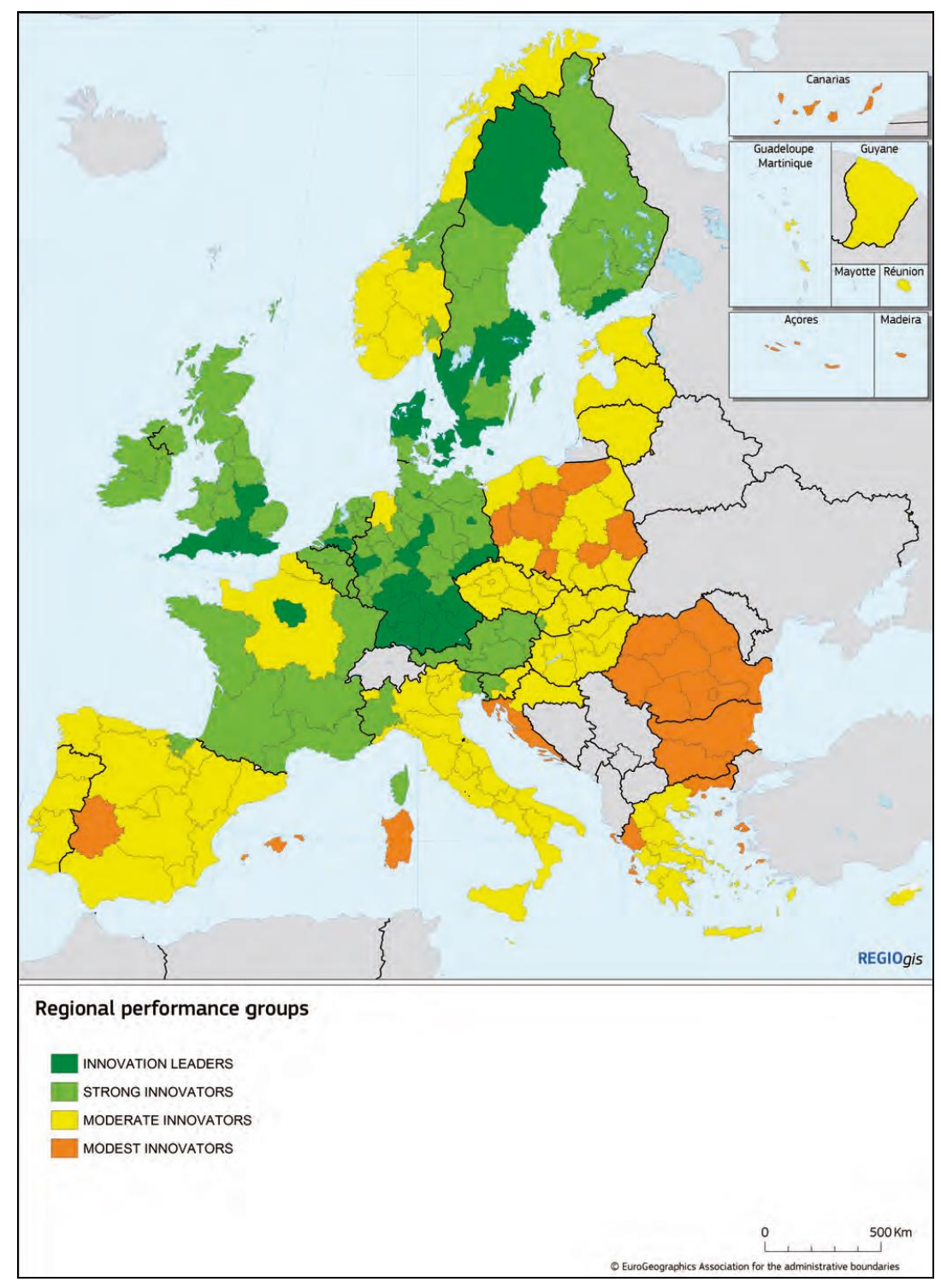

Figure 1. RII - Regional Performance Groups

Souces: European Commissione - European Innovation Scoreboard 2016 


\subsection{Regional Competitiveness Index (RCI), Regions and Data Availability}

National competitiveness, according to the World Economic Forum (WEF), is the "set of institutions, policies and factors that determine the level of productivity of a country" (Schwab, 2012; Schwab and Porter, 2007). This was developed to steer their well-known Global Competitiveness Index (GCI). This definition links firms to the country they operate in Companylevel competitiveness, i.e. a firm's capacity to compete, grow and be profitable (Martin et al., 2006), is a relatively uncontested concept. Applying the same concept to countries or regions, however, has given rise to criticism that a country or region cannot go out of business. In addition, competition between countries can be a positive sum game, while competition between companies tends to be a zero sum game (Krugman, 1996).

A region is neither a simple aggregation of firms nor a scaled version of nations (Gardiner et al., 2004). Meyer-Stamer (2008) states that: 'We can define (systemic) competitiveness of a territory as the ability of a locality or region to generate high and rising incomes and improve the livelihoods of the people living there.' This definition, however, is based entirely on the benefits to people living in a region and does not assess the strengths or weaknesses of the firms.

The European Commission has proposed a definition of regional competitiveness that integrates the perspective of both firms and residents (Dijkstra et al., 2011): "Regional competitiveness is the ability of a region to offer an attractive and sustainable environment for firms and residents to live and work". This definition balances the goals of business success with those of personal well-being. In this way, it responds to the discussion that gross domestic product (GDP) is insufficient by itself and should be complemented by a broader range of measures. In fact the term "sustainable" in this definition means a region's capacity to provide an attractive environment in both the short and long term.

As we know national competitiveness indicators benefit from a clearly defined geographical and political border. At the regional level, however, this becomes more complicated. Using political regions raises a number of problems. In highly centralised countries, such as Romania or Bulgaria, regions do not have an important policy role. In other countries, such as Germany, there is more than one regional level with a policy function (the Länder and Kreisse). Some political regions cover only part of their functional economic area, and small regions tend to have less data availability. Therefore, the RCI does not target political regions.

The RCI is based on the statistical, NUTS 2 regions with one important change: NUTS 2 regions that are part of the same functional urban area are combined. This ensures that the RCI fully captures the skills available in the local labour market. For example, a firm in Brussels can easily draw on the labour force living in Brabant Wallon or Vlaams-Brabant. These regions have a higher share of the population with a university degree than Brussels. So only looking at the qualifications of Brussels' residents would misrepresent the full skill set available to this firm. This different definition of regional and territorial areas compared to the Regional Innovation Index has made for this research not some difficulty in harmonizing the data. However, because of specific facts, it has been adequately resolved by 


\section{MlMacrothink}

aggregating the data of the policy regions defined by the RII with respect to functional features specified by the RCI.

The RCI is composed of 11 pillars that describe the different aspects of competitiveness (Table 2). They are classified into three groups: Basic, Efficiency and Innovation. The Basic group includes five pillars: (1) Institutions; (2) Macroeconomic Stability; (3) Infrastructure; (4) Health; and (5) Basic Education. These represent the key basic drivers of all types of economies. As a regional economy develops and advances in its competitiveness, factors related to a more skilled labour force and a more efficient labour market come into play as part of the Efficiency group. This includes three pillars: (6) Higher Education, Training and Lifelong Learning; (7) Labour Market Efficiency; and (8) Market Size. At the most advanced stage of a regional economy's development, drivers of improvement are part of the Innovation group, which consists of three pillars: (9) Technological Readiness; (10) Business Sophistication; and (11) Innovation.

Table 2. Indicators Available on the EU Regional Competitiveness Index

\begin{tabular}{ll}
\hline BASIC & \multicolumn{1}{c}{ Indicators } \\
\hline & Institutions regional \\
& Macroeconomic stability \\
& Infrastructure \\
& Health \\
& Basic Education \\
EFFICIENCY & Higher education \& lifelong learning \\
& Labour market efficiency \\
\hline INNOVATION & Market size \\
& Technological readiness regional \\
& Business sophistication \\
\hline
\end{tabular}

Source: Own processing on EU data, 2016

The RCI is the only measure to provide a European perspective on the competitiveness of all NUTS-2 regions in the EU. Through its 11 pillars, it assesses not only aggregate competitiveness but also the strengths and weaknesses of a region. The RCI takes a wider approach to competitiveness, looking at a number of relevant dimensions not strictly related to company productivity, but also covering societal well-being, and long-term potential. In so doing, it departs from traditional discourses which maintain that regional economic performance derives only from firms' competitiveness, and reflects the current debate on the fact that prosperity should not only be measured by income-related indicators but should include other aspects such as health and human capital development, (Stiglitz et al., 2009) and the EU's 'GDP and beyond' process (European Commission, 2009). Two pillars are described at the country level only: Macroeconomic stability and Quality of Primary and Basic Education. Macroeconomic stability is determined by actions taken by the national 


\section{Ml Macrothink}

Research in Applied Economics ISSN 1948-5433

2017, Vol. 9, No. 3

government and can therefore only be measured at the national level. Basic education is based on data from the Programme for International Student Assessment (PISA) by the OECD.

RCI score is computed for each region as the weighted average of the scores the region gets in the three groups (subindexes), with weights depending on the region's development stage. A geographical map of the regional performance groups is shown in Figure 2.

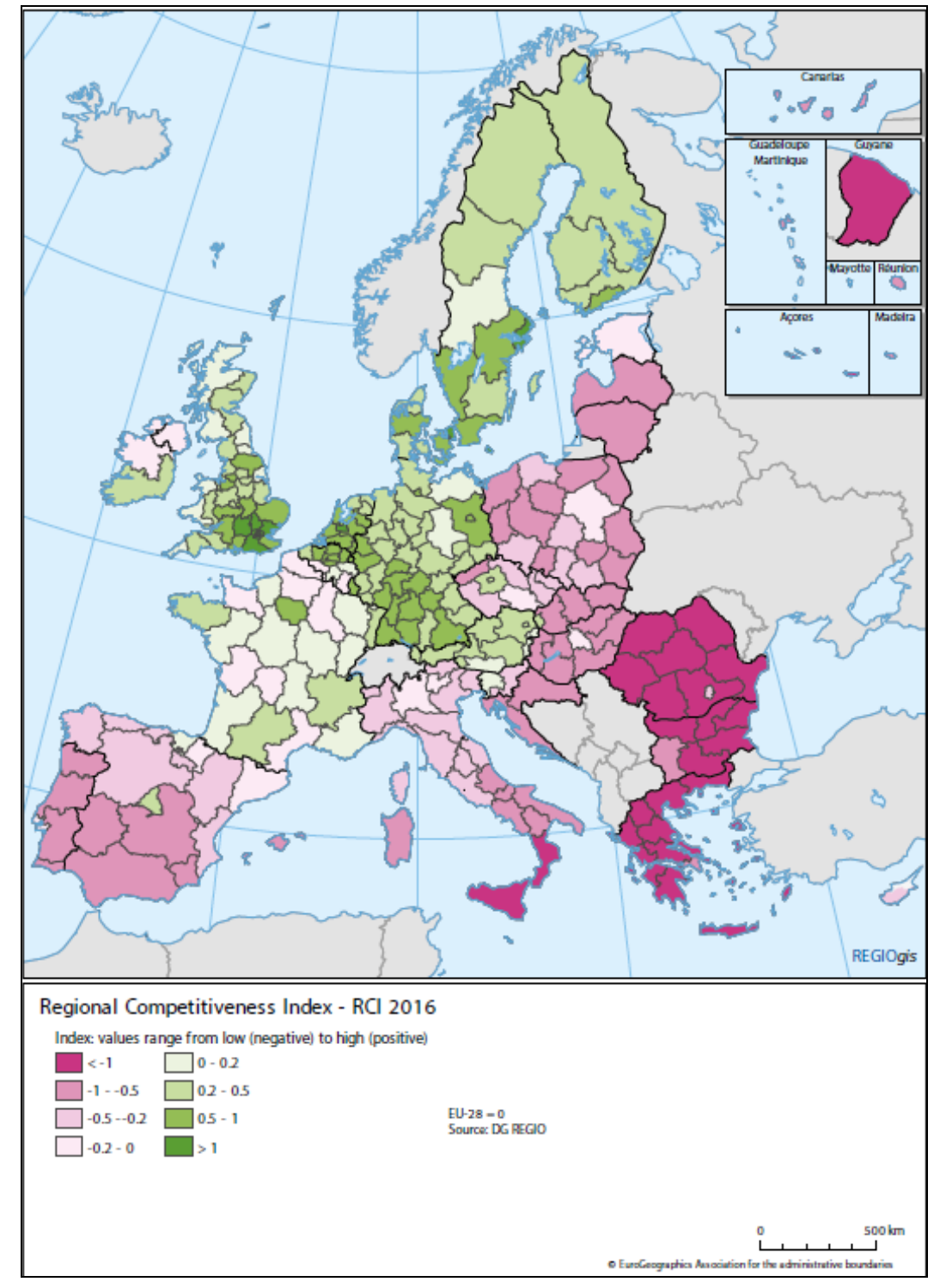

Figure 2. RCI - Regional Performance Groups

Souces: European Commissione - European Competitiviness Index 2016

\subsection{The Relationship between Innovation and Competitiveness in Europe}

We now move on to the central issue of this paper, namely the relationship between innovation and competitiveness. While on the one hand it is possible to say that innovation is a key driver of competitiveness in the modern economy, on the other hand, there is a 


\section{Al Macrothink}

Research in Applied Economics

ISSN 1948-5433

2017, Vol. 9, No. 3

significant contrast between factors and conditions that affect the behavior, the innovative performance, the determinants, the competitive ability of businesses and all territories. For these reasons it is necessary to highlight some of the complex links between innovation and competitiveness in order to reach appropriate policies.

Before evaluating the relationship between innovation and competitiveness framework of European regions, it is necessary to consider indicators of both the assessment models previously set out in the Regional Innovation Index and the Regional Competitviness Index. This analysis allows us to identify consistent indicators and to highlight the functional relationship between innovation and competitiveness. The following table shows the coherence between RII innovation and RCI innovation indicators. The highlighted indicators are those that appear in both indexes.

Table 3. Table of Consistency and Compatibility

\begin{tabular}{|c|c|}
\hline RII & RCI \\
\hline $\begin{array}{l}\text { Percentage population aged } 30-34 \text { having completed tertiary } \\
\text { education }\end{array}$ & Total patent applications \\
\hline R\&D expenditure in the public sector as percentage of GDP & Core Creativity Class employment \\
\hline R\&D expenditure in the business sector as percentage of GDP & Knowledge workers \\
\hline $\begin{array}{l}\text { Non-R\&D innovation expenditures as percentage of total } \\
\text { turnover }\end{array}$ & Scientific publications \\
\hline SMEs innovating in-house as percentage of SMEs & Total intramural R\&D expenditure \\
\hline $\begin{array}{l}\text { Innovative SMEs collaborating with others as percentage of } \\
\text { SMEs }\end{array}$ & $\begin{array}{l}\text { Human Resources in Science and Technology } \\
\text { (HRST) }\end{array}$ \\
\hline EPO patent applications per billion regional GDP (PPS€) & $\begin{array}{l}\text { Employment in technology and } \\
\text { knowledge-intensive }\end{array}$ \\
\hline $\begin{array}{l}\text { SMEs introducing product or process innovations as } \\
\text { percentage of SMEs }\end{array}$ & High-tech patents \\
\hline $\begin{array}{l}\text { SMEs introducing marketing or organisational innovations as } \\
\text { percentage of SMEs }\end{array}$ & ICT patents \\
\hline $\begin{array}{l}\text { Employment in medium-high and high tech manufacturing } \\
\text { and knowledge-intensive services as percentage of total } \\
\text { employment }\end{array}$ & Biotechnology patents \\
\hline $\begin{array}{l}\text { Exports of medium-high and high technology-intensive } \\
\text { manufacturing industries as percentage of total manufacturing } \\
\text { exports }\end{array}$ & $\begin{array}{l}\text { Exports in medium-high/high-tech } \\
\text { manufacturing }\end{array}$ \\
\hline $\begin{array}{l}\text { Sales of new-to-market and new-to-firm innovations as } \\
\text { percentage of total turnover Similar }\end{array}$ & $\begin{array}{l}\text { Sales of new to market and new to firms } \\
\text { innovation }\end{array}$ \\
\hline
\end{tabular}

Source: Own processing, EU data, 2016

Relating to these models and by presenting a comparative analysis of competitiveness and innovation indices, it is possible to explain how innovation factors are key elements of territorial competitiveness. Comparison of these measurement variables is reported on the 
following scatter diagram which show a positive association between the innovative and competitive performance of countries considered in this analysis. This explains how regional competitiveness indices reflect innovative performance. The axis of the ascites contains the values regarding the index of regional competitiveness, while the axis of the ordinates the values of the regional innovation index. Overtaking and comparing these values is a positive result that explains how innovation is considered a key factor in competitiveness. Indeed, the indices of regional competitiveness reflect the innovative performance.

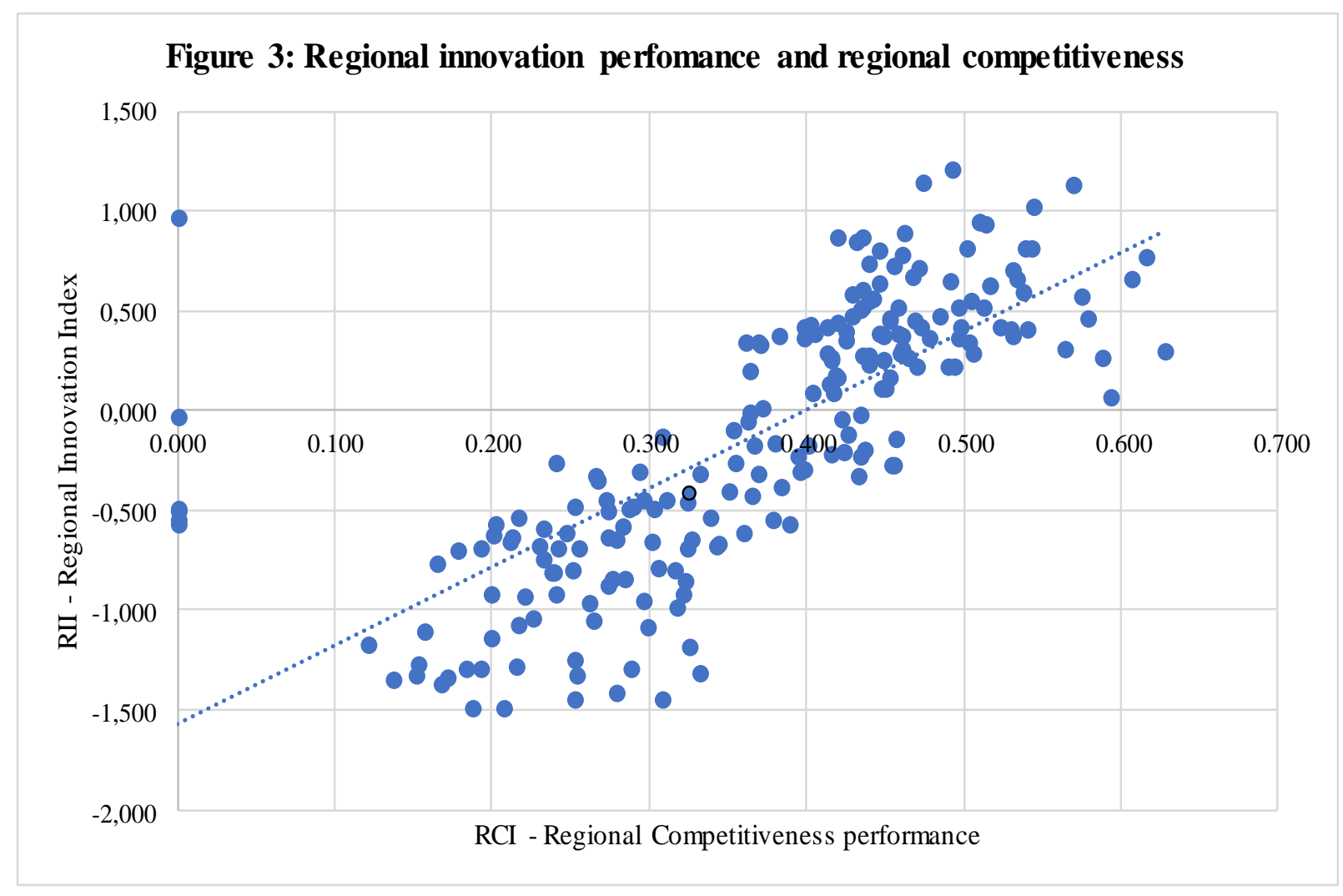

Figure 3. Regional Innovation Performance and Regional Competiveness

\section{The Role of Policy}

Strong and complex links between innovation performance and competitiveness have important implications for public policy. Understanding these links is important in designing policies and measures that target the global policy objectives set by the general public. Here attention is drawn to some of these implications, based on the discussion in the previous section.

At the macro level, it is possible to point out an important policy upshot of the close association between regional innovation and competitiveness performance, in particular the fact that innovation performance is an important driver of regional and territorial competitiveness. Therefore, policy measures that have a positive effect on innovation performance are likely to improve regional competitiveness as well. In consequence, such 
policy measures, if successful, will de facto enact a mutually reinforcing effect on regional economic performance, which will ultimately enhance their welfare effect.

Another important implication is related to the fact that both regional innovation performance and regional competitiveness depend on a wide array of factors, controlled by various stakeholders, within the public and private sectors, in the business and academic communities, and in civil society. This confluence is both a challenge and opportunity for policymakers. It is a challenge, as multi-stakeholder cooperation is time consuming and can involve lengthy and difficult coordination procedures. At the same time, it opens the opportunity to "hit two birds with one stone", as one and the same set of coordinated policies can address two important policy targets, synergising the efforts involved.

Yet a third important implication is related to the long-term nature of both innovation and competitiveness at the macro level. Related to that, public policies targeting to improve either regional innovation performance or regional competitiveness, or both, involve structural policy measures whose effect stretches well beyond the short term. In consequence, the design and implementation of such policy measures requires the establishment of a policyand decision-making environment, institutions, and mechanisms that take this long-term nature into account and ensure the continuity of policies over the political cycle. In terms of politics, ensuring such continuity implies an ongoing regional and local political dialogue involving the major regional and national players, on key regional priorities and specializations in the areas of innovation and competitiveness policies. This continuity on such regional priorities is a guarantee for implementing long-term policies.

Finally, regional innovation-based competitiveness is a complex and multidimensional phenomenon. Does not exist a unique relation betwen innovation and competitiviness but a complex mix of relations, actors, activities. Knowledge society or investment in R\&D alone is an important but insufficient condition for innovation based growth. In this regard, the notion of "regional innovation sistem" is a useful approach to account for the multifaceted nature of innovation in fully utilizing the potential for enhancing competitiveness and growth at the local and regional level. The underlying idea is that the innovation capacity of an regional economy depends not only on the supply of $R \& D$ and innovation but also on the capability to absorb and diffuse new technology and on the demand for its generation and utilization. From a policy perspective, the innovation capacity also depends on innovation governance, that is, on a set of institutions and rules that affect the innovation process.

At microeconomic level, the situation is more ambiguous due to the complex links and relationships between firm innovation performance and competitiveness. Public policies traditionally support firms' innovation-related activities. In the globalized modern economy, a firm's innovation activity involves complex links and interactions with other business entities as well as with public institutions, and is dependent on the efficient functioning of these links. This complex environment increases the risk of failures in different parts of the networks. As consequence., the rationale for policy intervention as well as the importance of the different types of policies involved have been changing with the evolution of the innovation processes. 
More specifically, these conclusions would suggest differentiated policy approaches to facilitate innovation performance. For example, these conclusions indicate that policy approaches which stimulate innovation activity in regions that are technological leaders, would not necessarily perform well in regions that are still catching up in their technological development. On the one hand, catching up regions need to attract foreign direct investment (FDI) into innovative and high-value added activities in order to raise the overall innovative performance of their economies. Secondly, they face the challenge of identifying and stimulating those linkages between FDI and the domestic economy that generate positive spillover effects, thus spurring a "virtuous circle" of asset accumulation and clustering. Thirdly, as argued above, they may need specific policies to stimulate the innovative performance of domestic firms.

Definitly recognising the multiple factors that influence innovation a common view has emerged favouring a broad mix of policy measures and platform policies over specific intervention favouring for instance a particular industry, knowledge base or mode of innovation (Cooke et al. 2007; Asheim, Boschma, and Cooke 2011). This approach demands a strong policy push promoting such a high road, innovation based regional development strategy (Asheim, Coenen, and Moodysson 2015).

\section{Conclusions}

The aim of this paper has been to enter in the debate on innovation and degree of competitiveness comparing first the dataset from the European Commission mapping the most innovative regions and one of the most competitive regions. In the light of this comparison has been possible to compare the correlation between the index of innovation and to regional competitiveness. The consensus of opinion, backed up by strong empirical evidence, is clearly that innovation has an important positive effect on competitiveness. The agreement starts to evaporate, however, when we ask whether there is enough of it; whether here should be more of it; and whether and how public policy can be used to stimulate it.

Estimates of rates of return to $R \& D$ certainly support the view that there is less $R \& D$ spending than is socially and economically desirable. This is perhaps particularly true in the EU, where only $2 \%$ of GDP is spent on R\&D, nearly a percentage point less than in Japan and the US. The challenge is to know how to increase it, when the evidence on the effectiveness of almost all public policies is mixed or virtually non-existent.

This paper has therefore tried to develop a more in-depth analysis of the issue of a Europe-wide relationship between innovation and competitiveness. We underline as this is a working paper with interesting developments both on the empirical basis and on the analysis of factors that contribute to making the regions and territories more competitive and in terms of policy indications.

Certainly all factors contributing to the competitiveness of a region are both endogenous and exogenous, and there are macroeconomic and nationally low-controllable elements among regional decision makers Moreover, the endogenous and territorial indicators included in the 
Regional Competitive Index are numerous and fairly wide. Only some of them refer to innovation. Nevertheless, the relationship between innovation and competitiveness remains always valid and decisive in regional policy choices and is one of the main research areas above all for the development of European policies. Hence, moving towards a dynamic understanding of this relationship, future research will be fundamental in understanding new paths development.

\section{References}

Agrawal, A., I. Cockburn \& J. McHale (2006). Gone but not forgotten: knowledge flows, labor mobility, and enduring social relationships. Journal of Economic Geography, 6(5), 571-591. https://doi.org/10.1093/jeg/lbl016

Aiginger, K. (2006). Competitiveness: from a dangerous obsession to a welfare creating ability with positive externalities. Journal of Industry, Competition and Trade, 6(2), 161-177. https://doi.org/10.1007/s10842-006-9475-6

Amin, A. (1999). An institutionalist perspective on regional economic development. International Journal of Urban and Regional Research, 23(2), 365-378. https://doi.org/10.1111/1468-2427.00201

Asheim B., Grillitsch M., \& Trippl M. (2015). Regional Innovation Systems: Past - Presence - Future, Centre for Innovation, Research and Competence in the Learning Economy (CIRCLE) - Lund University, Papers in Innovation Studies Paper no. 2015/36;

Asheim, B.T. (1996). Industrial districts as 'learning regions': A condition for prosperity. European Planning Studies, 4(4), 379-400. https://doi.org/10.1080/09654319608720354

Asheim, B.T. (2000). Industrial districts: The contributions of Marshall and beyond. In G.L. Clark, M.P. Feldman and M.S. Gertler (ed.), The Oxford handbook of economic geography, Oxford; New York: Oxford University Press, 413-431.

Asheim, B.T. (2007). Differentiated knowledge bases and varieties of regional innovation systems. Innovation: The European Journal of Social Science Research, 20(3), 223-241. https://doi.org/10.1080/13511610701722846

Asheim, B.T., \& A. Isaksen. (1997). Location, agglomeration and innovation: Towards regional innovation systems in Norway?. European Planning Studies, 5(3), 299-330. https://doi.org/10.1080/09654319708720402

Asheim, B.T., H.L. Smith \& C. Oughton. (2011). Regional Innovation Systems: Theory, Empirics and Policy. Regional Studies, 45(7), 875-891. https://doi.org/10.1080/00343404.2011.596701

Asheim, B.T., J. Moodysson \& F. Tödtling (2011). Constructing Regional Advantage: Towards State-of-the-Art Regional Innovation System Policies in Europe?. European Planning Studies, 19(7), 1133-1139. https://doi.org/10.1080/09654313.2011.573127 
Asheim, B.T., L. Coenen \& J. Moodysson (2015). Methods and applications of regional innovation systems analysis. In C. Karlsson, M. Andersson and T. Norman (ed.), Handbook of Research Methods and Applications in Economic Geography, Cheltenham: Edward Elgar, 272-290. https://doi.org/10.4337/9780857932679.00020

Asheim, B.T., R. Boschma \& P. Cooke. (2011). Constructing Regional Advantage: Platform Policies Based on Related Variety and Differentiated Knowledge Bases. Regional Studies, 45(7), 893-904. https://doi.org/10.1080/00343404.2010.543126

Audretsch, D., \& Keilbach, M. (2004). Entrepreneurship and regional growth: an evolutionary interpretation. Journal of Evolutionary Economics, 14(5), 605-616. https://doi.org/10.1007/s00191-004-0228-6

Baptista, R., \& P. Swann (1998). Do firms in clusters innovate more? Research Policy, 27(5), 525-540. https://doi.org/10.1016/S0048-7333(98)00065-1

Begg, I. (1999). Cities and competitiveness. Urban Studies, 36(5/6), 795-810. https://doi.org/10.1080/0042098993222

Benneworth, P. (2004). In what sense "regional development"? Entrepreneurship, underdevelopment and strong tradition in the periphery. Entrepreneurship and Regional Development, 16(6), 439-458. https://doi.org/10.1080/0898562042000249786

Benneworth, P., \& Charles, D. (2005). University spin-off policies and economic development in less successful regions: Learning from two decades of policy practice. European Planning Studies, 13, 537-557. https://doi.org/10.1080/09654310500107175

Bianchi, P., \& M.G. Giordani. (1993). Innovation policy at the local and national levels: The case of Emilia - Romagna. European Planning Studies, 1(1), 25-41. https://doi.org/10.1080/09654319308720193

Breschi, S., \& F. Lissoni. (2009). Mobility of skilled workers and co-invention networks: an anatomy of localized knowledge flows. Journal of Economic Geography, 9(4), 439-468. https://doi.org/10.1093/jeg/lbp008

Bristow, G. (2005). Everyone's a 'winner': problematising the discourse of regional competitiveness. Journal of Economic Geography, 5(3), 285-304. https://doi.org/10.1093/jeg/lbh063

Brusco, S. (1982). The Emilian model: productive decentralisation and social integration. Cambridge Journal of Economics, 6(2), 167-184.

Burt, R.S. (2000). The Network Structure Of Social Capital. Research in Organizational Behavior, 22(0), 345-423. https://doi.org/10.1016/S0191-3085(00)22009-1

Camagni, R. (1995). The concept of innovative milieu and its relevance for public policies in european lagging regions. Papers in Regional Science, 74(4), 317-340. https://doi.org/10.1111/j.1435-5597.1995.tb00644.x

Camagni, R. (2002). On the concept of territorial competitiveness: sound or misleading?. 
Urban Studies, 39, 2395-2411. https://doi.org/10.1080/0042098022000027022

Chaston, I. (2009). Entrepreneurs, intuition, and small-business performance. JCC: The Business and Economics Research Journal, 2(1), 37-45. https://doi.org/10.7835/jcc-berj-2009-0021

Clark J., \& Guy K. (1998). Innovation and competitiveness: a review. Technology Analysis \& Strategic Management, 10(3), 363-395. https://doi.org/10.1080/09537329808524322

Cooke, P. (1998). Introduction. Origins of the concept. In H.-J. Braczyk, P. Cooke and M. Heidenreich (ed.), Regional Innovation Systems: The Role of Governances in a Globalized World, London: UCL 2-25. https://doi.org/10.1007/978-1-4471-3985-0_1

Cooke, P. (2001). Regional Innovation Systems, Clusters, and the Knowledge Economy. Industrial and Corporate Change, 10(4), 945-974. https://doi.org/10.1093/icc/10.4.945

Courlet, C., \& Soulage, B. (1995). Industrial dynamics and territorial space. $\begin{array}{llll}\text { Entrepreneurship } \quad \& \quad \text { Regional Development, } & 7, & \text { 285-307. }\end{array}$ https://doi.org/10.1080/08985629500000019

Crevoisier, O. (2004). The Innovative Milieus Approach: Toward a Territorialized Understanding of the Economy?. Economic Geography, 80(4), 367-379. https://doi.org/10.1111/j.1944-8287.2004.tb00243.x

Dijkstra, L., Annoni P., Kozovska, K. (2011). A new European Regional Competitiveness Index: theory, methods and findings. DG Regional Policy Working Papers WP02/2011.

Dobrinsky R., (2008). Innovation as a key driver of competitiveness - UNECE Annual Report Economic Essays - unece.org.

EC - European Commission (2016). Directorate-General for Internal Market, Industry, Entrepreneurship and SMEs, Regional Innovation Scoreboard 2016.

EC - European Commission (2016). Directorate-General for Internal Market, Industry, Entrepreneurship and SMEs, European Innovation Scoreboards (EIS), Brussels.

EC - European Commission, (2017). The EU Regional Competitiveness Index 2016, A series of short papers on regional research and indicators produced by the Directorate-General for Regional and Urban Policy, Working Paper n. 02/2017.

Edquist, C. (1997). Systems of innovation: technologies, institutions, and organizations. London: Printer Publishers/Castell Academic.

Freeman, C. (1995). The 'national system of innovation' in historical perspective. Cambridge Journal of Economics, 19(1), 5-25.

Gardiner, B., Martin, R., \& Tyler, P. (2004). Competitiveness, productivity and economic growth across the European Regions. Regional Studies, 38(9), 1045-67. https://doi.org/10.1080/0034340042000292638 


\section{MInstitute Macrothink $_{\text {Int }}$}

Garofoli, G. (2002). Local development in Europe: theoretical models and international comparisons. European Urban and Regional Studies, 9, 225-239. https://doi.org/10.1177/096977640200900303

Gertler, M.S. (2004). Manufacturing culture: the institutional geography of industrial practice. Oxford: Oxford University Press.

Granovetter, M. (1973). The streangth of weak ties. The American Journal of Sociology, 78(6), 1360-1380. https://doi.org/10.1086/225469

Granovetter, M. (2005). The Impact of Social Structure on Economic Outcomes. The Journal of Economic Perspectives, 19(1), 33-50. https://doi.org/10.1257/0895330053147958

Grillitsch, M., F. Tödtling \& C. Höglinger. (2013). Variety in knowledge sourcing, geography and innovation: Evidence from the ICT sector in Austria. Papers in Regional Science.

Howells, J. (1999). Regional systems of innovation?'. In D. Archibugi, J. Howells and J. Michie (ed.), Innovation policy in a global economy, Cambridge: Cambridge University Press, 67-92. https://doi.org/10.1017/CBO9780511599088.007

Huggins R., \& Johnston A. (2009). Knowledge networks in an uncompetitive region: SME growth and innovation. Growth and Change, 40, 227-259. https://doi.org/10.1111/j.1468-2257.2009.00474.x

Huggins, R. (1997). Regional competitive specialization: Development agency sector $\begin{array}{llll}\text { initiatives in } \quad \text { Wales. 29(3), } & \text { 241-252. }\end{array}$ https://doi.org/10.1111/j.1475-4762.1997.tb00026.x

Huggins, R. (2003). Creating a UK competitiveness index: regional and local benchmarking. Regional Studies, 37(1), 89-96. https://doi.org/10.1080/0034340022000033420

Huggins, R., \& Izushi, H. (2007). Competing for Knowledge: Creating, Connecting, and Growing, London: Routledge.

Huggins, R., \& Williams, N. (2009). Enterprise and public policy: a review of Labour government intervention in the United Kingdom. Environment and Planning $C$ : Government and Policy, 27, 19-41. https://doi.org/10.1068/c0762b

Huggins, R., \& Williams, N. (2011). Entrepreneurship and regional competitiveness: the role and progression of policy. Entrepreneurship and Regional Development, 23(9/10), 907-932. https://doi.org/10.1080/08985626.2011.577818

Kitson, M., Martin, R., \& Tyler, P. (2004). Regional competitiveness: An elusive yet key concept?" Regional Studies, 38, 991-999. https://doi.org/10.1080/0034340042000320816

Krugman, P. (1994). Competitiveness: a dangerous obsession. Foreign Affairs, 73(2), 28-44. https://doi.org/10.2307/20045917 
Krugman, P. (1996). Making sense of the competitiveness debate. Oxford Review of Economic Policy, 12(3), 17-25. https://doi.org/10.1093/oxrep/12.3.17

Krugman, P. (2003). Growth on the Periphery: Second Wind for Industrial Regions? Glasgow, UK: Fraser Allander Institute.

Lagendijk, A., \& Lorentzen, A. (2007). Proximity, knowledge and innovation in peripheral regions. On the intersection between geographical and organizational proximity. European Planning Studies, 15(4), 457-466. https://doi.org/10.1080/09654310601133260

Lawson, C., \& Lorenz, E. (1999). Collective learning, tacit knowledge and regional innovative capacity. Regional Studies, 33, 305-317. https://doi.org/10.1080/713693555

Leborgne, D., \& Lipietz, A. (1988). New technologies, new modes of regulation: some spatial implications. Environment and Planning D: Society and Space, 6, 263-280. https://doi.org/10.1068/d060263

Lee, S. Y., Florida, R., \& Acs, Z. J. (2004). Creativity and entrepreneurship: a regional analysis of new firm formation. Regional Studies, 38(8), 879-891. https://doi.org/10.1068/d060263

Lundvall, B.-A. (1992). National systems of innovation: towards a theory of innovation and interactive learning. London: Pinter.

Maillat, D. (1998a). Interactions between urban systems and localized productive systems: an approach to endogenous regional developement in terms of innovative milieu. European Planning Studies, 6(2), 117-130. https://doi.org/10.1080/09654319808720450

Maillat, D. (1998b). Innovative milieux and new generations of regional policies. Entrepreneurship and Regional Development, 10, 1-16. https://doi.org/10.1080/08985629800000001

Malecki, E. J. (2004). Jockeying for position: what it means and why it matters to regional development policy when places compete. Regional Studies, 38(9), 1101-1120. https://doi.org/10.1080/0034340042000292665

Malecki, E. J. (2007). Cities and regions competing in the global economy: knowledge and local development policies. Environment and Planning C: Government and Policy, 25(3), 638-654. https://doi.org/10.1068/c0645

Malmberg, A., \& P. Maskell (1999). The Competitiveness of Firms and Regions: 'Ubiquitification' and the Importance of Localized Learning. European Urban and Regional Studies, 6(1), 9-25. https://doi.org/10.1177/096977649900600102

Marshall, A. (1920). Principles of economics: an introductory volume. London: Macmillan.

Martin, R. (2005). Thinking About Regional Competitiveness: Critical issues, Report Commissioned by the East Midlands Regional Development Agency, Nottingham, UK: East Midlands Regional Development Agency. 
Martin, R., Kitson, M., \& Tyler, P. (eds) (2006). Regional Competitiveness, London, UK and New York, NY, USA: Routledge.

Maskell, P. (2001). Towards a knowledge-based theory of the geographical cluster. Industrial and Corporate Change, 10(4), 921-943. https://doi.org/10.1093/icc/10.4.921

Moulaert, F., \& F. Sekia (2003). Territorial innovation models: a critical survey. Regional Studies, 37(3), 289-302. https://doi.org/10.1080/0034340032000065442

Nelson, R.R. (1993). National Innovation Systems: A Comparative Analysis. Oxford: Oxford University Press.

North, D., \& Smallbone, D. (2000). Innovative activity in SMEs and rural economic development: some evidence from England. European Planning Studies, 8, 87-106. https://doi.org/10.1080/096543100110947

Plum, O., \& R. Hassink (2013). Analysing the knowledge base configuration that drives southwest Saxony's automotive firms. European Urban and Regional Studies 20(2), 206-226. https://doi.org/10.1177/0969776412454127

Polanyi, M. (1958). Personal knowledge: towards a post-critical philosophy. London: Routledge \& Kegan Paul.

Porter, M.E. (1998). Clusters and the new economics of competition. Harvard business review, 76(6), 77-90.

Putnam, R.D. (1995). Bowling alone: America's declining social capital. Journal of democracy, 6(1), 65-78. https://doi.org/10.1353/jod.1995.0002

Pyke, F., G. Becattini \& W. Sengenberger (1990). Industrial districts and inter-firm cooperation in Italy. Geneva: International Institute for Labour Studies.

Quadrio Curzio A. - Fortis M. - Galli G. (a cura di) (2002). Competitività, ricerca ed innovazione in Italia. Roma, Il Sole 24 ore.

Quadrio Curzio A. - Fortis M. (a cura di) (2007). Valorizzare un'economia forte. L'Italia e il ruolo della sussidiarietà, Bologna, Il Mulino.

Rossi L., \& Raimondi A. (2007). Investimenti, innovazione e competitività. Economia Politica, XXIV, 2.

Schwab, K. (ed.) (2012). The Global Competitiveness Report 2012-2013. Geneva, Switzerland: World Economic Forum.

Schwab, K., \& Porter, M.E. (2007). The Global Competitiveness Report 2007-2008. Geneva, Switzerland: World Economic Forum.

Storper, M. (1997). The Regional World: Territorial Development in a Global Economy. New York: Guilford Press.

Swann, P., \& M. Prevezer. (1996). A comparison of the dynamics of industrial clustering in 
computing and biotechnology. Research Policy, 25(7), 1139-1157. https://doi.org/10.1016/S0048-7333(96)00897-9

Tödtling, F., \& M. Trippl. (2004). Like Phoenix from the Ashes? The Renewal of Clusters in Old Industrial Areas. Urban Studies, 41(5-6), 1175-1195. https://doi.org/10.1080/00420980410001675788

Tödtling, F., \& M. Trippl. (2005). One size fits all? Towards a differentiated regional innovation policy approach. Research Policy, 34(8), 1203-1219. https://doi.org/10.1016/j.respol.2005.01.018

Tödtling, F., B.T. Asheim \& R. Boschma. (2013). Knowledge sourcing, innovation and constructing advantage in regions of Europe. European Urban and Regional Studies 20(2), 161-169. https://doi.org/10.1177/0969776412457173

Virkkala, S. (2007). Innovation and networking in peripheral areas: a case study of emergence and change in rural manufacturing. European Planning Studies, 15(4), 511-529. https://doi.org/10.1080/09654310601133948

\section{Note}

Note 1. The annual country-level reports have been published under the name "European Innovation Scoreboard" until 2009, as "Innovation Union Scoreboard" (IUS) between 2010 and 2015, and once again as "European Innovation Scoreboard" from 2016 onwards.

\section{Copyright Disclaimer}

Copyright for this article is retained by the author(s), with first publication rights granted to the journal.

This is an open-access article distributed under the terms and conditions of the Creative Commons Attribution license (http://creativecommons.org/licenses/by/3.0/). 